\title{
Varieties of Sovereignty
}

and Citizenship 


\section{DEMOCRACY, CITIZENSHIP, AND CONSTITUTIONALISM}

Rogers M. Smith and Mary L. Dudziak, Series Editors

A list of books in the series is available from the publisher. 


\section{Varieties of Sovereignty and Citizenship}

Edited by

Sigal R. Ben-Porath

and

Rogers M. Smith

\section{$\overline{\text { PENN }}$}

UNIVERSITY OF PENNSYLVANIA PRESS

Philadelphia 
Copyright @ 2013 University of Pennsylvania Press

All rights reserved. Except for brief quotations used for purposes of review or scholarly citation, none of this book may be reproduced in any form by any means without written permission from the publisher.

Published by

University of Pennsylvania Press

Philadelphia, Pennsylvania 19104-4112

www.upenn.edu/pennpress

Printed in the United States of America on acid-free paper

$\begin{array}{llllllllll}10 & 9 & 8 & 7 & 6 & 5 & 4 & 3 & 2 & 1\end{array}$

Library of Congress Cataloging-in-Publication Data

Varieties of sovereignty and citizenship / edited by Sigal R. Ben-Porath and Rogers M. Smith. - 1st ed.

p. cm. - (Democracy, citizenship, and constitutionalism)

Includes bibliographical references and index.

ISBN 978-0-8122-4456-4 (hardcover : alk. paper)

1. Sovereignty-History-20th century. 2. Sovereignty-History-21st century. 3. Citizenship-History-20th century. 4. Citizenship-History21st century. 5. Nation-state-History-20th century. 6. Nation-stateHistory-21st century. I. Ben-Porath, Sigal R. II. Smith, Rogers M.

JC327.V37 2013

$320.1^{\prime} 5-\mathrm{dc} 23$ 